\title{
A Project for Implementation of the Feuerstein's Instrumental Enrichment Programme in Adult Literacy
}

\author{
Carlos Eduardo de Carvalho Vargas* \\ Pontifical Catholic University of Paraná, Curitiba, Brazil \\ *Corresponding author: carlos.vargas@ibge.gov.br
}

Received September 12, 2014; Revised December 02, 2014; Accepted December 14, 2014

\begin{abstract}
This project aims to provide an effective methodology and innovative local action in the area of youth and adults education. Justifying in the Brazilian social context and relying on the theory of the Dr. Reuven Feuerstein's mediated learning, a strategy of action will be presented to cognitively improve the performance of young people and adults in the literacy process.
\end{abstract}

Keywords: Reuven Feuerstein, philosophy of education, adult literacy

Cite This Article: Carlos Eduardo de Carvalho Vargas, "A Project for Implementation of the Feuerstein's Instrumental Enrichment Programme in Adult Literacy." American Journal of Educational Research, vol. 2, no. 12C (2014): 11-13. doi: 10.12691/education-2-12C-4.

\section{Introduction}

The objective of this paper is to present a concrete proposal for the application of the Feuerstein's Instrumental Enrichment Programme (FIE), as an aid for adult literacy resource, and briefly describe its theoretic foundations and provide extra resources to the planning of stages of the project and its evaluation. This project aims to be sufficiently robust to ensure its sustainability and maintenance by themselves after an initial incentive.

The Feuerstein's Instrumental Enrichment Programme has been applied to diverse populations of students, from children with learning difficulties to workers in industries and students in universities. He is considered very important in the Israeli experience of research and assessment in the development of intelligence theory. "Reuven Feuerstein, an internationally acclaimed professor of educational psychology at Bar-Ilan University in Israel, carried out groundbreaking work in the development of dynamic assessment procedures and systematic intervention materials for modifying the cognitive competencies of non-mainstream student populations" (Zeidner, Mattews, Roberts, 2004, p. 236).

The Feuerstein's Instrumental Enrichment Programme has a broad international recognition. It has been translated into most of the European languages and some Asian languages, being used in over 40 countries (Vargas, 2007). The Feuerstein's Instrumental Enrichment Programme also resulted in a large number of experimental, clinical and educational studies, have been published about 1500 articles and about 40 books on the subject (Hoffman, Feuerstein, 1990, p. 115).

The justification of research and its theoretical framework recovers a summary of the Feuerstein's philosophy of education that was presented in a paper published in a Brazilian journal of philosophy and psychology of education (Vargas, 2007).

\section{Development of the Project}

\subsection{Mediators and Students}

The first step of this project is the choice of the target audience, defining the students and mediators that will participate in the project. For students, there is no greater difficulties if we assume, as the theoretical framework of the theory of Feuerstein, that everyone can improve cognitively. We depart from the presupposition that every human being has the possibility to learn more efficiently, since they go through the proper mediation. The most appropriate is to contact some center of youth and adult education already working in adult literacy and offer a partnership.

Feuerstein, Rand and Rynders (1988, p. 210) offered an interesting suggestion to organize the students: "the program is initiated, preferably in a classroom situation, which can vary in size from 10 to 30 children, depending on the level of their functioning and the variation in their need for individual mediator interaction. Preference for group teaching (versus individual instruction) stems from our belief that, if the group is properly guided by the teacher/mediator, the diversity of that group can foster divergent thinking and enrich the interactions of participants". Detailed descriptions of each of the instruments Feuerstein are available in the works of Sasson and Macionk (2001a, 2001b, 2001c), Skuy (1999) and Feuerstein (1980, p. 125-226).

The choice of mediators will not be difficult as there are many who are already trained and certainly would be interested in participating in such a benevolent project. Furthermore, it is possible to enable new mediators, even as part of the project. Although rigorous, the training of mediators is available to educators in general. All training 
centers authorized by the International Center for the Enhancement of Learning Potential (ICELP) are listed in the "web page" of ICELP

(http://www.icelp.org/asp/Authorized_Training_Centers3. asp?id=13).

Another important aspect of this choice of mediators is a remarkable structure that has already been installed in Brazil, enabling excellent penetration into the project. There are centers for training mediators in the Southeast (São Paulo, Belo Horizonte and Rio de Janeiro), South (Curitiba and Canoas), Central-West (Brasilia) and Northeast (Salvador). This distribution centers in Brazil provides an application of the method in a considerable part of the country.

In addition, new mediators can be formed, even if not reside in these cities, because the course of mediator can be done in modules per week, for example, as in Curitiba (http://www.cdcp.com.br), where mediators were already formed. When finish the first level the participant can start the application of the instruments on which it was trained. The limit on the number of students in a class of the Instrumental Enrichment Programme is the limit of the maintenance of quality of the mediation. A reasonable amount would be the number of students in a class of youngs and adults education, for example.

\subsection{Obtaining the Material}

Feuerstein, Rand and Rynders (1988, p. 209) explained the Instrumental Enrichment Programme: "instrumental enrichment is a program composed of two major elements: a set of materials-the "instruments" -and an elaborate teaching system based on mediated learning experience. The materials consist of a set of 14 instruments (clusters of exercises) with names faintly descriptive of their specific content, such as Organization of Dots, Orientation in Space, Analytical Perception, Comparisons, and Categorization."

The material of Instrumental Enrichment Program can be applied at a relatively low cost. This acquisition can be done in any Authorized Training Centers (ATC), that is listed in the ICELP's home page (http://www.icelp.org/asp/Authorized_Training_Centers3. asp?id=13). The 14 instruments of Instrumental Enrichment Program have an application order recommended by the Institute of Professor Feuerstein, which is already known by the mediators trained.

However, this sequence is not mandatory, but may be modified depending on several methodological factors. In the case of application of Feuerstein's Instrumental Enrichment Programme in the adult literate, it is recommended to start by instruments that require less ability to read and write, as instruments for organizing points, going slowly for instruments that require a bit more literacy and advancing steadily.

\subsection{Duration of the Course}

Based on the context of implementing the instruments of Feuerstein's Instrumental Enrichment Programme in adult literacy, the following sequence of application of the pages is recommended. One motto of the Feuerstein's Instrumental Enrichment Programme is "a moment, let me think", which indicates a certain flexibility in deadlines, but we can estimate the average duration of one to two pages per session. Following a periodicity of 2 sessions per week, although the course can even be daily, one would have a duration of about 18 weeks for the first four instruments, which may be called the FIE-1.

From this point, when the literacy would likely to be more advanced, you can follow a sequence of Feuerstein's Instrumental Enrichment Programme adapted to the literacy level of students. One can then make the sequence of FIE-2 (CDCP, 2002c). This will include 104 sheets, which is equivalent to approximately 52 sessions, which will require about 36 weeks.

Thus, the period of the first two steps (FIE-1, FIE-2) will complete about 54 weeks or 12 months. Considering the holidays during this period, the course can be planned for 14 months. The remaining four instruments (Transitive Relations and Syllogisms, for example), which form the FIE-3, will be proposed as a motivator for students to continue doing the FIE after the end of the "first phase" of the project. From this FIE-3, i.e., from the "second stage", the project should be consolidated to continue more autonomously.

\subsection{Sustainability of the Project}

Once started, the project tends to sustain itself and even generate some financial return that could, for example, return to the community involved. The proof of that sustainability is the work of several of mediators who are already trained in Brazil and working with the method. Whereas the material cost is low, the cost of training would be low, as can be parceled out. Another advantage is that the Feuertein's Instrumental Enrichment Programme can be, practically, done in any environment, as it requires only a place where students can remain seated, the cost to the government or entity organizer would not be relatively high, since there is a multiplying capacity in the project itself.

At first, it is not necessary to invest in training, because the project can start with mediators already formed. Maybe the project should invest more in the case of increasing the number of students. However, it is recommended to take advantage of the budget in the first year to train new mediators who can work on the expansion project, considering its high capillarity.

A form of sustainability for the project after the first year's work would be to charge small fees, depending on the financial condition of the community. Moreover, a way of multiplying the project would be to coordinate the work of mediators already formed or the formation of new mediators in the first year so that they could assist in this expansion project.

\subsection{Assessment of Project}

The project could be assessed as the English experience was described by Nigel Blagg (1991), i.e., by means of questionnaires that can be filled by mediators responsible for this assessment. So, it is possible to quantify some aspects of the project in statistical terms. For example, the assessment questionnaire may be answered at the beginning of the course, being filled. So, it will be possible to compare the results of the training, as did Nigel Blagg (1991, p 76-79) in his British experience.

As this assessment questionnaire is faithfully based on the criteria of an authentic Feuerstein's Instrumental Enrichment Programme and respective theory, it provides a reasonably safe rate of the quality of mediation and 
learning. The results of this evaluation concerning the work of the mediator should be discussed between the mediators and the organizers of the project.

As for the results of all the students in the class, these can be discussed in a general way with the class itself, using graphs and tables, which will be an opportunity to practice these forms of information presentation. After discussion with the class and expressed in graphs and tables, the statistical results of all the students should be transmitted to the rest of the community involved. Particular cases should be discussed particularly with the students.

Following Nigel Blagg (1991), in the mediator's observation form we can have itens about class organization, introduction of session, final of session, the way of discussion in the group, mediation of individual activities, general criteria of mediation and conduct of students and their learning.

Inspired in Nigel Blagg (1991), we can indicate some pedagogical topics to the evaluation of the application of the Feuerstein's Instrumental Enrichment Programme: the mediator should create a pleasant environment in the class, arranging chairs and tables to provide a good visual contact among students. In the introduction of session, the mediator should care to the students enter in the room in an orderly manner, that the session begins stimulating manner, explaining the objectives of the session clearly to students.

In the final session, the mediator should has an appropriate time for him and the students do the feedback of that session, doing the output of the students in an orderly manner. In the group, the students should be encouraged to contribute in class discussions. The Feuerstein's Instrumental Enrichment Programme offers many pedagogical possibilities and the instructor must work properly and creatively to the cognitive development of its students.

\section{Conclusions}

Upon completion of this project is expected that the Feuerstein's Instrumental Enrichment Programme may represent a positive contribution in adult education and literacy. In this project, we also expected to have been clear about the practical aspects of the project: its justification, its duration, its reach and sustainability. By performing this educational project, will be offered a great opportunity for adult learners of literacy courses to improve their cognitive structure.

The great originality of this project is the method itself, the idea of turning it into a public policy and the practical application of Feuerstein's Instrumental Enrichment Programme to adult literacy. However, this final consideration will be added the following observation: the benefits of the application of Feuerstein's Instrumental Enrichment Programme are not only cognitive, although this aspect has been further emphasized in the theoretical framework. Students will also benefit in their self-esteem and integration of personality. They will be not only smarter people, but will also be better people. This is one of the major goals of the learning mediation.

\section{References}

[1] Blagg, N. Can We Teach Intelligence? A Comprehensive of Feuerstein's Instrumental Enrichment. Hillsdale: Lawrence Erlbaum Associates, 1991. 217p.

[2] CDCP. Experiência de Aprendizagem Mediada - EAM. CDCP, 2001. Avaiable in: http://www.cdcp.com.br/pindex.htm.

[3] Zeidner, M., Matthews, G., Roberts, R. Intelligence Theory, Assessment, and Research: The Israeli Experience. In: Sternberg, R. (ed.). International Handbook of Intelligence. Cambridge: Cambridge University Press, 2004, pp. 212-247.

[4] Feuerstein, R. Instrumental enrichment: an intervention program for cognitivie modifibility. Glenview: Scott, Foresman and Company: 1980.

[5] Feuerstein, R., Falik, L. H., Feuerstein, R. The learning Potential Assessment Device: Na Alternative Approach to the Assessment of Learning Potential. In Samuda, R., Feuerstein, R. et alli. Advanced in Cross-Cultural Assessment. Thousand Oaks: London: New Delhi: Sage Publications, 1998. 311p.

[6] Feuerstein, R., Hoffman, M. B. Mediating Cognitive Processes to the Retarded Performer - Rationale, Goals, and Nature of Intervention. In: Schwebel, M., Fagley, N. S., Maher, C. A. Promoting Cognitive Growth Over the Life Span. Hillsdale: Lawrence Erlbaum Associates, 1990.

[7] Feuerstein, R., Hoffman, M. B. et alli. Learning to Learn: Mediated Learning Experiences and Instrumental Enrichment. In: Schwebel, M. S., Maher, C. A.(org.). Facilitating Cognitive Development: International Perspectives, Programs, and Practices. 1986. New York: The Harworth Press, 1986.

[8] Feuerstein, R., Rand, Y., Rynders, J. Don't Accept me as I am: Helping "Retarded" People to Excel. Dordrecht: Springer Science+Business Media, 1988. 322p.

[9] Greenberg, K. H. The Cognitive Enrichment Advantage Teacher Handbook. Knoxville: KCD Harris \& Associates Press, 2000. 240p.

[10] Gibson, G. D. Cognitive Literacy: A 21 st Century Imperative for Education and Community Revitalization. In: UNEVOC Canada \& ICELP International Conference: Unlocking The Human Potential To Learn. Manitoba: UNEVOC: ICELP, 2001.

[11] Hoon, A. S., Seng, T. O. Mediating Learning Experience. In: Fisher, C. B., Lerner, R. M. (org.). Encyclopedia of Applied Developmental Science. Thousand Oaks: London: New Delhi: Sage Publications, 2005.1298p.

[12] Moraes, R. Direito à inteligência: o educador Reuven Feuerstein aplica no ensino público baiano seu método revolucionário que afirma que todos são capazes de aprender. In: Revista Istoé, $\mathrm{N}^{\circ}$ 1545, 12 de maio de 1999. São Paulo: Editora 3, 1999. Avaiable in http://www.cdcp.com.br/pindex.htm.

[13] Sasson, D. Programa de Enriquecimento Instrumental do Prof. Feuerstein - PEI. Curitiba: CDCP, 2000. Avaiable in: http://www.cdcp.com.br/pindex.htm.

[14] Sasson, D. Educador de educadores: o papel do gestor como mediador de seus professores. In: Gestão educacional: novembro, 2005. Curitiba: Humana Editorial, 2005.

[15] Sasson, D. Todos são capazes de mudar e aprender mais: método de aprendizado promove modificação da capacidade intelectual entrevista. Curitiba: Gazeta do Povo, 29 jan. 2006. p. 11.

[16] Sasson, D., Macionk, M. Curso de Formação - PEI -Nível 1Organização de Pontos, Orientação Espacial 1, Comparações, Percepção Analítica. Curitiba: CDCP, 2001a.

[17] Sasson, D., Macionk, M. Curso de Formação - PEI -Nível 2Classificações, Relações Familiares, Ilustrações, Orientação Espacial II, Relações Temporais. Curitiba: CDCP, 2001 b.

[18] Sasson, D., Macionk, M. Curso de Formação - PEI -Nível 3Progressões Numéricas, Instruções, Silogismos, Relações Transitivas, Desenho de Padrões. Curitiba: CDCP, 2001c.

[19] Sasson, D., Macionk, M. FAQ - Frequently Asked Questions. Curitiba: CDCP, 2001d. Avaiable in: http://www.cdcp.com.br/pindex.htm.

[20] Skuy, M., Mentis, M., Feuersten, R. Bridgind Learning In and Out of the Classroom. Arlington Heights: SkyLight Training and Publishing, 1999. 134p.

[21] Vargas, C. Elementos de Filosofia da Educação a partir da Teoria da Modificabilidade Cognitiva Estrutural de Feuerstein. Aprender: Caderno de Filosofia e Psicologia da Educação, Vitória da Conquista, Ano V, n. 8, p. 145-159, 2007. 